\title{
Managing diameter growth and natural pruning of Parana pine, Araucaria angustifolia (Bert.) O Ktze., to produce high value timber
}

\author{
Leif NUTTO $^{\mathrm{a}}$, Peter SPATHELF ${ }^{\mathrm{b} *}$, Robert ROGERS ${ }^{\mathrm{c}}$ \\ a Avenida da Galicia no 5, Parque Tecnologico da Galicia, San Cibrao das Viñas, 32901 Ourense, Spain \\ ${ }^{b}$ Forstdirektion Tübingen, Im Schloss, 72074 Tübingen, Germany \\ ${ }^{c}$ Forestry Faculty, College of Natural Resources, University of Wisconsin-Stevens Point, Stevens Point, Wisconsin 54481, USA
}

(Received 13 June 2003; accepted 10 May 2004)

\begin{abstract}
The objective of the present work was to analyse diameter growth and the relationship of natural pruning and various morphological characteristics of Parana pine (Araucaria angustifolia (Bert.) O Ktze.) growing on different sites in southern Brazil and to formulate silvicultural strategies for producing high quality timber for this species. Data on four hundreds trees in both natural and planted forests were collected on temporary sample plots each containing 25 Parana pines. The size of the knotty core within Parana pine stems was modeled with the predictor variables height of the lowest dead branch, height to crown base and maximum radial increment of stem at $1.3 \mathrm{~m}$. The results of our study show that crown width is a good estimator of diameter growth and is closely related to stem diameter at $1.3 \mathrm{~m}$ above ground. Restricting crown expansion such that average annual radial increment is $4 \mathrm{~mm} /$ year at $1.3 \mathrm{~m}$ for a stem grown for 63 years compared to one grown for 36 years with less crown restriction such that the average annual radial increment is about $75 \%$ greater $(7 \mathrm{~mm} / \mathrm{year})$ results in a knotty core volume that is about $75 \%$ less for the slower growing tree. Managers can use this model to guide silvicultural decisions needed to achieve the production goal of high quality wood of Parana pine.
\end{abstract}

growing space / diameter growth / high valued timber / natural pruning / artificial pruning

Résumé - Gérer la croissance en diamètre et l'élagage naturel du pin du Parana (Araucaria angustifolia (Bert.) O Ktze. pour produire un bois de haute valeur. L'objectif de ce travail a été d'analyser la croissance en diamètre et les relations entre l'élagage naturel et différentes caractéristiques du Pin de Parana (Araucaria angustifolia (Bert.) O Ktze) poussant dans différents sites dans le sud du Brésil et de formuler des stratégies sylvicoles pour produire du bois de haute qualité. Quatre cents arbres dans des peuplements naturels et plantés ont été collectés dans des placettes temporaires comprenant chacune 25 arbres. La grosseur des cœurs branchus dans les trouées a été modélisée avec des variables prédictives : hauteur de la plus basse branche morte, hauteur de la base de la couronne et accroissement radial maximum à 1,3 m. Les résultats de l'étude montrent que la largeur de la couronne est un bon estimateur de la croissance en diamètre et qu'elle est étroitement reliée au diamètre du tronc à 1,3 m. La limitation de l'expansion de la couronne de telle manière que l'accroissement annuel moyen atteigne $4 \mathrm{~mm} / \mathrm{an}$ à $1,3 \mathrm{~m}$ pour un arbre ayant poussé depuis 63 ans en comparaison avec un autre qui a poussé depuis 36 ans avec une limitation moindre de la croissance de la couronne tel que l'accroissement en diamètre soit d'environ $75 \%$ plus grand $(7 \mathrm{~mm} / \mathrm{an})$, a pour résultat un volume de nœud plus faible d'environ $75 \%$ que pour l'arbre ayant poussé plus lentement. Les aménagistes peuvent utiliser ce modèle pour les guider et décider des sylvicultures nécessaires pour atteindre un objectif de production de bois de haute qualité.

espace de croissance / croissance en diamètre / bois de haute valeur / élagage naturel / élagage artificiel

\section{INTRODUCTION}

\subsection{Occurrence}

There are only 14 species in the genus Araucaria within the Araucariaceae family and all these species occur in the southern hemisphere [37]. Parana pine (Araucaria angustifolia (Bert.) O. Ktze.) is one of two species occurring in South Amer- ica and is of major economic value in the world marketplace [15]. However, the export volume of Parana pine was limited by the Brazilian Institute of Agriculture and Environment because of fears that continued and increasing demand with concomitant high export volumes would push Parana pine to extinction [13]. Therefore between 1995 and 1998 the Brazilian government allowed a volume of only $52000 \mathrm{~m}^{3}$ per year of Parana pine to be exported. Thus, the potential for this species

\footnotetext{
* Corresponding author: Peter.Spathelf@rpt.bwl.de
} 
to produce high valued wood is one reason why it is interesting to study.

Parana pine is naturally found between the latitudes of $15^{\circ}$ and $30^{\circ}$ South and between $43^{\circ}$ and $57^{\circ}$ East longitude. High concentrations of Parana pine are found in the Brazilian states of Rio Grande do Sul, Santa Catarina, and Paraná with lesser concentrations in São Paulo, Minas Gerais, Rio de Janeiro and in the Argentine province of Misiones [12].

Parana pine is found at altitudes from $600 \mathrm{~m}$ to a maximum of $1800 \mathrm{~m}$ in the Mantiqueira mountains (Rio de Janeiro). The climate where Parana pine naturally occurs is classed as subtropical humid with a mean annual temperature between 13 and $18^{\circ} \mathrm{C}$ and relatively cool winters reaching $-8{ }^{\circ} \mathrm{C}$ but with a low frequency for frost [10, 22]. Annual rainfalls vary between 1500 and $2000 \mathrm{~mm}$.

\subsection{Species characteristics and management}

Parana pine is a light demanding species, although in its youth it is moderately shade tolerant. Regeneration under the canopy is possible as well as growth on open land (behaviour of pioneer). The crown of Parana pine is characterised by whorls with on average 4 to 8 branches. The lowest dead branch is not necessarily constituted by a complete whorl. In Rio Grande do Sul and Santa Catarina, where cambial activity of tree growth is inhibited by cold winter temperatures, tree growth of various native species is annual, proven by dendrochronological methods. However, we observed that especially on good sites several annual shoots can be established. In general no epicormics emerge.

In southern Brazil most of the commercial Parana pine commonly grows in pure stands and is harvested at a rotation age of approximately 30 years. Wood products include pulp for paper and cardboard, timber for construction, and veneer. Mean annual increment varies from 10 to $25 \mathrm{~m}^{3} \mathrm{ha}^{-1} \mathrm{yr}^{-1}$.

In the past Parana pine covered more than 20 million hectares of the southern Brazilian landscape. However, the growing need for agricultural land and pasture as well as wood for construction and other purposes led to the large-scale exploitation and destruction of these forests. By 1980 less than three percent of the native forests of Parana pine were left [17]. Today Parana pine competes with species of pine (Pinus) and Eucalyptus (Eucalyptus) throughout its former natural range [8]. These species now form the raw material base for the southern Brazilian pulp and paper industries because of their high growth in volume. High quality Parana pine timber could establish an additional base of wood grown for cellulose besides pine and eucalypts and could justify increasing the area of Parana pine forests on an economic basis. Sterba [34] recommends using endangered native species on ecological grounds for sustainable management of both natural and artificial forests. Over the last few years, system-oriented research has become increasingly popular for developing models that describe biological patterns or processes which in turn become useful in developing "ecological" management systems. Pretzsch [26] gives a helpful overview over modeling approaches and modeling categories in the field of forest growth analysis. He cautions that to manage species in uneven-aged stands or multi-layered stands of mixed species, growth modeling techniques currently being applied to even-aged stands need to be modified in order to be useful for forestry practitioners who need to manage uneven-aged stands. For this purpose, single-tree models are very promising. Examples of such models for tree species in Southern Germany include the work done by Spiecker [33] and Nutto [24] that predict various growth characteristics of individual trees and Nutto and Spiecker [25] who in combination with modeling the growth dynamics of trees also predict wood quality.

\subsection{Modeling for high quality timber production}

The most important characteristics of trees that influence quality of timber produced for sawlogs or veneer are diameter and knottiness [10]. Producing large diameter trees growing in dense stands often requires a long rotation period. However, individual tree diameter growth can be increased by thinning stands to reduce stand density thereby shorting the usual rotation time to produce large diameter trees. The liability in thinning stands, particularly early in the rotation, is the likelihood that natural pruning of branches will be delayed leading to lower wood quality. In this case, artificial pruning may be necessary to produce high quality wood free of knots. But we also need to consider that species differ in regard to the extent and timing of natural pruning. Some species, particularly broadleaved trees like oak or beech loose their branches easily. However, conifers retain dead branches for a long time such that they often become partly enclosed by the bole of the tree thereby resulting in a large volume of knotty core [19] (Fig. 11).

Branches that are shaded by parts of the upper crown or the crowns of neighboring trees reduce their photosynthesis and soon become disconnected from the assimilation distribution system. From this time onward, they only respire and do not contribute to tree growth any longer. If light intensity continues to fall, the branch begins to die [14]. This process is known as natural pruning. According to Mitscherlich and von Gadow [20] branches in the lower part of the crown can even reduce diameter increment because of assumed losses due to respiration.

Fortunately, trees have physiological mechanisms to respond to the trauma caused by biotic or abiotic damage or assimilatory inefficiency which leads to the loss of branches. Stem cells at the base of the branches create barrier zones to prevent the entrance of debilitating organisms into the stem. This process is called "compartmentalization" [32]. The natural pruning process of Parana pine is considered to be good in comparison to other coniferous trees. Nonetheless, Seitz [31] recommends artificially pruning Parana pine to produce high quality wood in a reasonable time especially if the diameter goal is relatively small $(40$ to $50 \mathrm{~cm})$

We reasoned that to optimize producing high quality timber, we need to know what impact silvicultural treatments have on the process of natural pruning. For most tree species we know that stem diameter growth can be expressed as a linear function of crown expansion with good predictability power. Therefore rapid diameter growth of the tree needs to be sustained by a rapid expansion of the crown which in turn means larger branches to support the increased leaf area. Thus, for modeling purposes we selected an individual tree approach. In fact, linear models describing the relationship between branch diameter and branch length have already been documented for several species [5, 23, 24]. This research shows that longer branches 
Table I. Characteristics of measured variables.

\begin{tabular}{|c|c|c|c|c|c|c|}
\hline Plot & $\mathrm{n} / \mathrm{p} / \mathrm{s}^{1}$ & $\begin{array}{c}\text { Age }^{2} \\
\text { (years) }\end{array}$ & $\begin{array}{c}d b h \\
\min -\max \\
(\mathrm{cm})\end{array}$ & $\begin{array}{l}\text { Height }\left(\mathrm{h}_{\mathrm{dom}}\right) \\
\min -\max ^{3} \\
(\mathrm{~m})\end{array}$ & $\begin{array}{c}\text { Crown projection } \\
\text { area } \\
\left(\mathrm{m}^{2} / \text { tree }\right)\end{array}$ & $\begin{array}{c}\text { Site } \\
\text { index }\end{array}$ \\
\hline $\begin{array}{l}\text { FLONA São Francisco } \\
\text { de Paula -RS- }\end{array}$ & $\begin{array}{l}\mathrm{p} \\
\mathrm{p} \\
\mathrm{p} \\
\mathrm{p}\end{array}$ & $\begin{array}{l}33 \\
33 \\
35 \\
35\end{array}$ & $\begin{array}{c}8.4-26.0 \\
12.0-9.1 \\
8.4-15.0 \\
12.0-45.0\end{array}$ & $\begin{array}{l}13.6 \\
15.6 \\
10.1 \\
18.2\end{array}$ & $\begin{array}{l}1.2-14.6 \\
1.3-18.6 \\
1.8-11.8 \\
2.6-53.0\end{array}$ & $\begin{array}{l}17 \\
20 \\
13 \\
22\end{array}$ \\
\hline $\begin{array}{l}\text { CELUCAT } \\
\text {-SC- }\end{array}$ & $\begin{array}{l}\mathrm{p} \\
\mathrm{n} \\
\mathrm{p} \\
\mathrm{s}^{5}\end{array}$ & $\begin{array}{c}26 \\
- \\
28 \\
-\end{array}$ & $\begin{array}{l}13.1-33.6 \\
15.9-70.3 \\
14.6-30.6 \\
9.5-128.3\end{array}$ & $\begin{array}{c}19.4 \\
12.9-26.8 \\
19.0 \\
5.0-38.4\end{array}$ & $\begin{array}{c}2.2-28.6 \\
6.6-144.4 \\
2.8-29.4 \\
7.2-391.6\end{array}$ & $\begin{array}{l}28 \\
- \\
27 \\
-\end{array}$ \\
\hline $\begin{array}{l}\text { ARAUPEL } \\
\text {-PR- }\end{array}$ & $\begin{array}{l}\mathrm{p} \\
\mathrm{n} \\
\mathrm{p} \\
\mathrm{p} \\
\mathrm{p} \\
\mathrm{p} \\
\mathrm{p} \\
\mathrm{p}\end{array}$ & $\begin{array}{c}21 \\
- \\
7 \\
10 \\
23 \\
32 \\
24 \\
49\end{array}$ & $\begin{array}{c}7.6-21.6 \\
4.9-51.9 \\
6.4-15.8 \\
7.6-20.4 \\
10.0-22.7 \\
24.8-47.7 \\
25.5-42.5 \\
36.5-60.6\end{array}$ & $\begin{array}{c}12.6 \\
4.9-21.2 \\
9.2 \\
13.4 \\
15.3 \\
22.8 \\
23.42 \\
30.4\end{array}$ & $\begin{array}{c}1.6-10.5 \\
2.1-49.3 \\
2.2-6.0 \\
2.6-13.4 \\
2.3-14.0 \\
6.9-50.4 \\
12.2-35.2 \\
26.7-95.8\end{array}$ & $\begin{array}{c}21 \\
- \\
34 \\
34 \\
24 \\
29 \\
34 \\
32\end{array}$ \\
\hline
\end{tabular}

$1 \mathrm{n} / \mathrm{p} / \mathrm{s}=$ native forest/planted forest/single trees; ${ }^{2}$ age (years since planting); ${ }^{3}$ height (maximum and minimum) for single trees and native forests (only Parana pines); ${ }^{4}$ after Schneider and Oesten [29], dominant height $\left(\mathrm{h}_{\mathrm{dom}}\right)$ at reference age of 50 years; ${ }^{5}$ age of some single trees known because they were planted.

mean larger branch stem diameters. Thus, rapid crown expansion delays natural pruning of trees because of the increased diameter growth of branch stem diameters [24, 33]. This means that if we want to minimize the knotty core within stems, we need to maintain high stand densities to retard rapid crown expansion in young stands [25]. Accelerating natural pruning by maintaining high initial stand densities is called "qualification" [33].

Thus, the objective of our study is to:

(i) analyse diameter growth and the relationship of natural pruning and various morphological characteristics of Parana pine,

(ii) and to formulate silvicultural strategies for producing high quality timber for this species.

Under high quality timber we understand large timber $(d b h>$ $40 \mathrm{~cm}$ ) free from knots at least in the lowest part of the stem to produce sawn-wood.

\section{MATERIALS AND METHODS}

\subsection{Location of stands and their characteristics}

For the study 16 stands were selected at random from both natural forests dominated by Parana pine and plantations found within three areas: (1) National Forest of São Francisco de Paula (RS) (29 $27^{\circ} \mathrm{S}$ $50^{\circ} 25^{\prime}$ E), (2) Celucat Company lands in Correia Pinto (Santa Catarina) (27 $34^{\prime} \mathrm{S} 50^{\circ} 22^{\prime} \mathrm{E}$ ), and (3) Araupel Company lands in Quedas do Iguaçu (Paraná) (25' $\left.28^{\prime} \mathrm{S} 52^{\circ} 54^{\prime} \mathrm{E}\right)$.

Stands selected in plantations varied from receiving no silvicultural treatments to intermediate thinnings using individual tree selection or row thinnings at various times (precise time in most cases could not be identified). Initial spacing of the planted stands were either $2 \times$ $1.5 \mathrm{~m}, 2 \times 2 \mathrm{~m}$, or $3 \times 2 \mathrm{~m}$. No genetic information concerning the analysed trees was available. The minimum and maximum values of measured characteristics of sample stands selected from the natural forest are shown in Table I.

\subsection{Working steps}

We established certain working steps that our study was to consider. These are discussed below and illustrated in Figure 1. A tree's growth is determined by various factors, among them site quality, spacing and age. Both diameter and height growth influence the dynamics of natural pruning (Fig. 1).

The energy converting area of the tree is its crown whereby in the presence of sunlight the photosynthetic process converts light energy to chemical energy. Thus the crown is very important for all growth process of the tree, including stem diameter and stem height growth.

Our first working step is that crown width can be expressed as a function of $d b h$. This is not new. In 1903 the French forester Duchaufour [7] described the relationship between tree diameter and crown dimension of Fagus silvatica as a possible base for a management tool. In 1963 Dawkins [4] published a set of linear and non-linear equations using these variables for different tropical tree species. In general diameter growth is a consequence of crown expansion and the equation would be $d b h$ as a function of a crown variable. But, if we want to control diameter growth or obtain a certain goal diameter, we have to express the equation as follows:

$$
\text { crown width }=\mathrm{f}(d b h) \text {. }
$$

For Parana Pine such a relationship has already been developed by several authors and will be discussed later $[16,31,36]$. Crown width is a two-dimensional estimator for the amount of growing space that a tree needs to produce a certain diameter increment. Crown width will be derived from crown projection area (see section sample selection and measurements).

The second working step is that the maximum (or potential) radial increment, $i r_{1.3 \max }$, of a tree is a function of site index, SI

$$
i r_{1.3 \max }=\mathrm{f}(\mathrm{SI})
$$




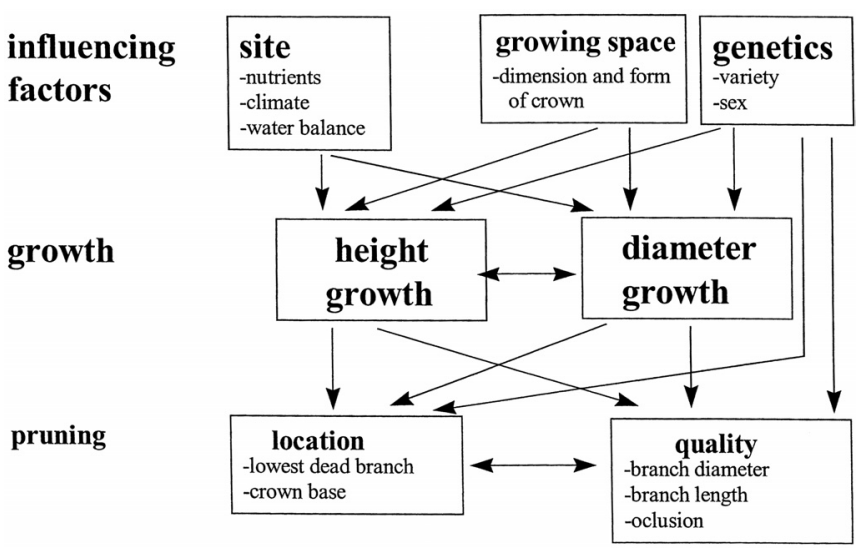

Figure 1. Inter-relationship between the influencing factors, growth and the dynamics and quality of natural pruning.

where $i r_{1.3 \max }$ is maximum radial increment at $1.3 \mathrm{~m}$ and $\mathrm{SI}$ is site index, index age $=50$ years [29]. Maximum radial increment at $1.3 \mathrm{~m}$ was calculated by averaging of diameter and age of the five largest trees per plot.

The third working step is that the height of the crown base above ground is a function of the tree's $d b h$, total height, and age

height of crown base $=\mathrm{f}(d b h$, total height, age $)$.

Height of crown base is defined as the height of the first living branch of the tree above ground.
The fourth working step is closely related to the third because we think that the height above ground of the lowest dead branch (commercial height) should be related to the height of the crown base

commercial height (lowest dead branch) $=\mathrm{f}$ (height of crown base). (4)

The last working step is that the functions that we develop to describe individual characteristics of trees can be combined into a model [9] that will predict the knotty core of a tree and thus allow us to determine the volume of the valuable knot free portion of the stem.

\subsection{Sample selection and measurements}

The sampling unit consisted of a central tree and its potential competitors (surrounding trees). A preliminary study to determine variability of important tree characteristics showed that it was sufficient to use 24 surrounding trees per central tree. The first tree in every sampling unit was randomly selected from outside the stand using a randomly generated distance and angle. This tree was given the coordinates $(0,0)$. All other trees were located using polar coordinates with reference to the tree at the origin. $D b h$, height of first dead branch, height of crown base, total height, and eight crown radii using variable angles were measured on all trees. We believe that using eight crown radii at variable angles represents the best compromise between accuracy and measurement efficiency when trying to estimate the crown projection area of trees with asymmetric crowns $[11,27,33]$. These data were used to generate stem and crown distribution maps (Fig. 2).

Crown projection area was determined by applying the triangular method [27] to the polygons formed by the crown measurements.

The area of a polygon consisting of several trees was determined using a digitizer. The percentage of the ground covered by canopy was calculated as the difference between the polygonal area and the sum of the crown projection areas within the polygon. This difference is important to know because not all of the area in a stand is used by tree

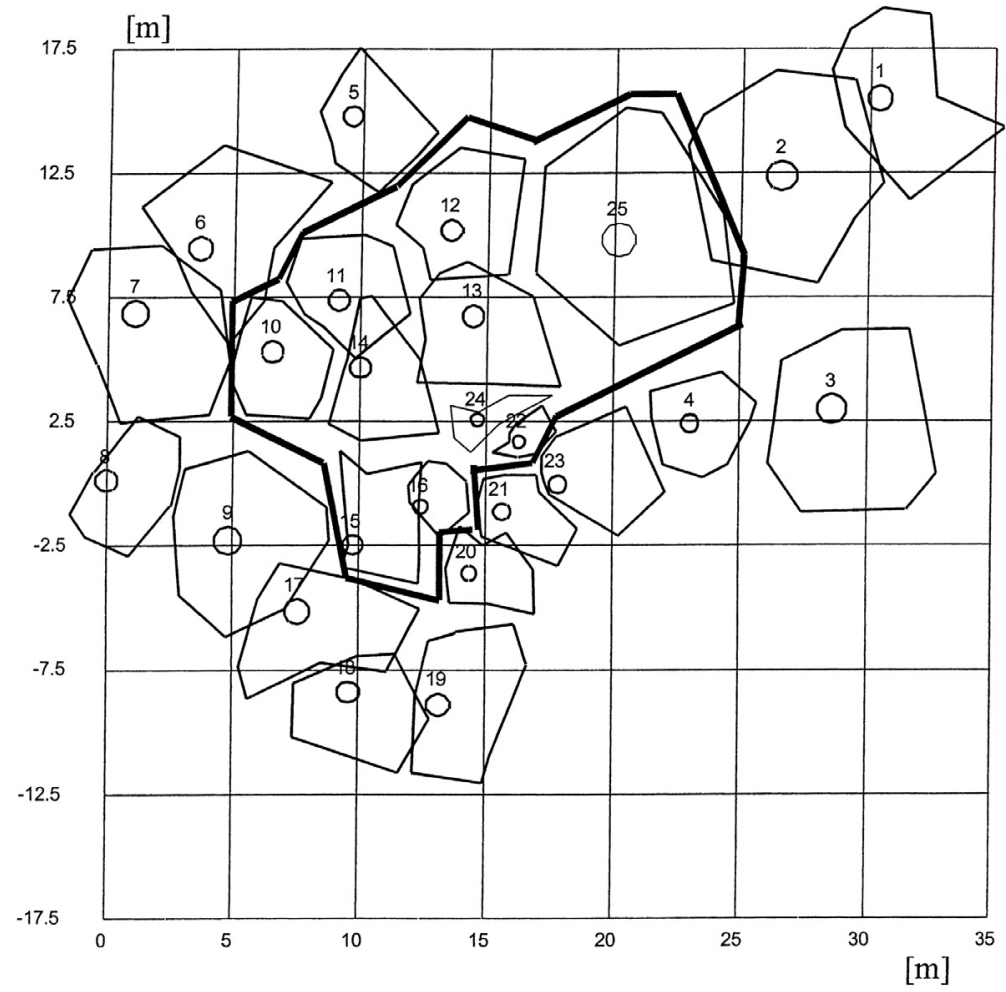

Figure 2. Tree distribution map showing crown projection areas of Parana pine (35 years old). Crown cover percentage of the dominant trees was calculated within the emphasized area. 
Table II. Pearsons simple correlation coefficients $(r)$ among the various measured variables on Parana pine $(N=400 \text { trees })^{*}$.

\begin{tabular}{lllllllll}
\hline & $c p a$ & $b a$ & $c w$ & $d b h$ & $c b$ & $l d b$ & $h$ & Age \\
\hline$c p a$ & & 0.94 & 0.94 & 0.90 & 0.63 & 0.66 & 0.63 & 0.64 \\
$b a$ & & 0.89 & 0.93 & 0.73 & 0.76 & 0.82 & 0.66 \\
$c w$ & 0.94 & 0.89 & & 0.96 & 0.61 & 0.70 & 0.77 & 0.88 \\
$d b h$ & 0.94 & 0.93 & 0.96 & & 0.77 & 0.79 & 0.91 & 0.91 \\
$c b$ & 0.90 & 0.73 & 0.61 & 0.77 & & 0.91 & 0.75 \\
$l d b$ & 0.63 & 0.76 & 0.70 & 0.79 & 0.91 & & 0.72 \\
$h$ & 0.66 & 0.82 & 0.77 & 0.88 & 0.91 & 0.87 & 0.64 \\
Age & 0.63 & 0.66 & 0.62 & 0.66 & 0.91 & 0.72 & 0.64 \\
\hline
\end{tabular}

* cpa $=$ crown projection area; $b a=$ basal area of the individual tree; $c w=$ crown width; $d b h=$ diameter at breast height; $c b=$ height of crown base; $l d b=$ height of lowest dead branch; $h=$ height.

crowns. This unused space may exist for a number of reasons including a reduced crown size because of tree and branch movement and subsequent branch breakage due to wind or reduction in stocking level because of natural disturbances (storm damage, ice damage, etc.) [24,33].

Crown width of each tree was calculated assuming the crown projection area of the tree to be a circle (crown width $=\sqrt{4} \times$ crown proj. $\operatorname{area} / \pi)$.

\section{RESULTS AND DISCUSSION}

\subsection{Crown width model}

A correlation analysis of data from all 400 trees showed a highly significant $(p<0.01)$ correlation between all variables measured including crown projection area and basal area of individual trees (Tab. II). However, we used stem $d b h$ and crown width to facilitate model development (see explanation in section materials and methods).

We regressed crown width on $d b h$ in order to develop a prediction equation for crown width but the distribution of errors about the regression line showed a non-constant variance (Fig. 3). This problem was solved by using a square root transformation on crown width and including a quadratic term for $d b h$.

The resulting model is

$$
c w^{0.5}=0.939+0.0473 d b h-0.000154 d b h^{2} \ldots
$$

where $c w$ is crown width $(\mathrm{m})$ and $d b h(\mathrm{~cm})$ is diameter at $1.3 \mathrm{~m}$ above ground; $R^{2}=0.93, S_{\mathrm{y} . \mathrm{x}}=0.171$, all coefficients significant $(P<0.05)$ (Fig. 4$)$.

\subsection{Maximum radial increment}

The model of crown width in relation to $d b h$ does not include site quality. Site quality, however, influences how fast trees grow in stem diameter, crown expansion, and height. Stand density is also known to influence crown expansion (and therefore stem diameter) and to a lesser extent on tree height. Thus trees in a free to grow condition will attain maximum growth rates limited by site index. These relationships need to be con-
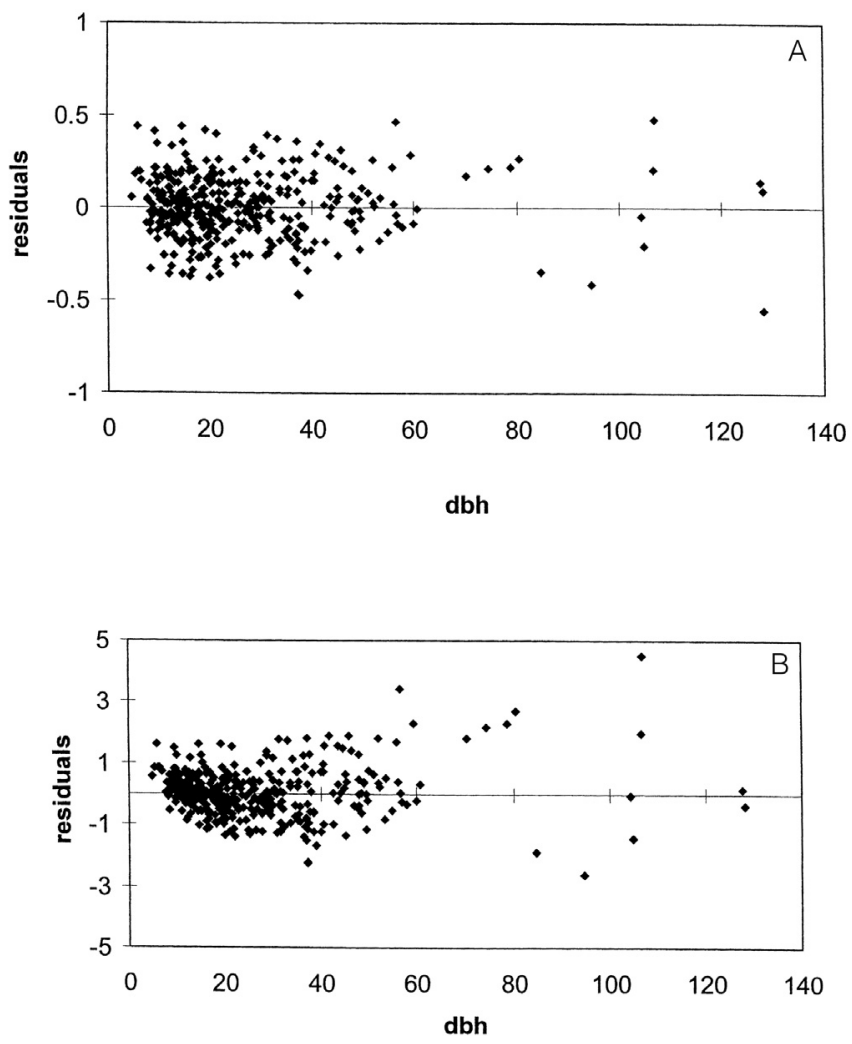

Figure 3. Residual plots of the transformed (A) and original (B) model.

sidered when developing silvicultural tools designed to regulate crown size by manipulating growing space.

Indeed, we found a strong relationship expressed by a quadratic equation between maximum radial increment of the stem and site index (Fig. 5). The regression equation is:

$$
i r_{\max }=3.2067-0.1945 \mathrm{SI}+0.0119 \mathrm{SI}^{2} \ldots
$$

where $i r_{\max }$ is maximum radial increment and SI is site index [29]; $R^{2}=0.91, S_{\mathrm{y} . \mathrm{x}}=1.12$, all coefficients significant $(P<0.05)$. 
Table III. Crown width $(\mathrm{cw})$ requirements according to age, site index and radial increment $(\mathrm{ir})^{*}$.

\begin{tabular}{|c|c|c|c|c|c|c|c|c|c|c|c|c|c|c|c|c|c|c|c|c|c|}
\hline \multirow{2}{*}{$\begin{array}{l}\text { Age } \\
{[y r]}\end{array}$} & \multicolumn{3}{|c|}{$i r=3$} & \multicolumn{3}{|c|}{$i r=4$} & \multicolumn{3}{|c|}{$i r=5$} & \multicolumn{3}{|c|}{$i r=6$} & \multicolumn{3}{|c|}{$i r=7$} & \multicolumn{3}{|c|}{$i r=8$} & \multicolumn{3}{|c|}{$i r=9$} \\
\hline & $d b h$ & $c w$ & $N$ & $d b h$ & $c w$ & $N$ & $d b h$ & $c w$ & $N$ & $d b h$ & $c w$ & $N$ & $d b h$ & $c w$ & $N$ & $d b h$ & $c w$ & $N$ & $d b h$ & $c w$ & $N$ \\
\hline 10 & 6 & 1.8 & 3145 & 8 & 2.1 & 2311 & 10 & 2.3 & 2098 & 12 & 2.6 & 1508 & 14 & 3.0 & 1132 & 16 & 3.3 & 936 & 18 & 3.6 & 786 \\
\hline 15 & 9 & 2.2 & 2106 & 12 & 2.6 & 1508 & 15 & 3.1 & 1926 & 18 & 3.6 & 786 & 21 & 4.2 & 578 & 24 & 4.7 & 461 & 27 & 5.3 & 363 \\
\hline 20 & 12 & 2.6 & 1508 & 16 & 3.3 & 936 & 20 & 4.0 & 1060 & 24 & 4.7 & 461 & 28 & 5.5 & 337 & 32 & 6.3 & 257 & 36 & 7.2 & 197 \\
\hline 25 & 15 & 3.1 & 1060 & 20 & 4.0 & 637 & 25 & 4.9 & 637 & 30 & 5.9 & 293 & 35 & 6.9 & 214 & 40 & 8.0 & 159 & 45 & 9.1 & 123 \\
\hline 30 & 18 & 3.6 & 786 & 24 & 4.7 & 461 & 30 & 5.9 & 424 & 36 & 7.2 & 197 & 42 & 8.5 & 141 & 48 & 9.8 & 106 & 54 & 11.1 & 83 \\
\hline 35 & 21 & 4.2 & 578 & 28 & 5.5 & 337 & 35 & 6.9 & 293 & 42 & 8.5 & 141 & 49 & 10.0 & 102 & 56 & 11.6 & 76 & 63 & 13.1 & 59 \\
\hline 40 & 24 & 4.7 & 461 & 32 & 6.3 & 257 & 40 & 8.0 & 214 & 48 & 9.8 & 106 & 56 & 11.6 & 76 & 64 & 13.3 & 58 & 72 & 15.1 & 45 \\
\hline 45 & 27 & 5.3 & 363 & 36 & 7.2 & 197 & 45 & 9.1 & 159 & 54 & 11.1 & 83 & 63 & 13.1 & 59 & 72 & 15.1 & 45 & & & \\
\hline 50 & 30 & 5.9 & 293 & 40 & 8.0 & 159 & 50 & 10.2 & 123 & 60 & 12.5 & 65 & 70 & 14.7 & 47 & 80 & 16.8 & 36 & & & \\
\hline 55 & 33 & 6.5 & 241 & 44 & 8.9 & 129 & 55 & 11.3 & 98 & 66 & 13.8 & 54 & 77 & 16.1 & 39 & & & & & & \\
\hline 60 & 36 & 7.2 & 197 & 48 & 9.8 & 106 & 60 & 12.5 & 80 & 72 & 15.1 & 45 & & & & & & & & & \\
\hline 65 & 39 & 7.8 & 168 & 52 & 10.7 & 89 & 65 & 13.6 & 65 & 78 & 16.4 & 38 & & & & & & & & & \\
\hline 70 & 42 & 8.5 & 141 & 56 & 11.6 & 76 & 70 & 14.7 & 55 & & & & & & & & & & & & \\
\hline 75 & 45 & 9.1 & 123 & 60 & 12.5 & 65 & 75 & 15.7 & 47 & & & & & & & & & & & & \\
\hline 80 & 48 & 9.8 & 106 & 64 & 13.3 & 58 & 80 & 16.8 & 41 & & & & & & & & & & & & \\
\hline $\begin{array}{l}\text { SI of maximum } \\
\text { ir }\end{array}$ & 15 & & & 19 & & & 23 & & & 26 & & & 28 & & & 30 & & & 32 & & \\
\hline
\end{tabular}

* $c w=$ crown width $(\mathrm{m})$ for a canopy covering percentage of $80 \%$; $i r=$ maximum average annual increment at height of $1.30 \mathrm{~m}(\mathrm{~mm} / \mathrm{yr})$ that can be reached at the indicated SI; SI = site index; $d b h=$ diameter at breast height; $N=$ number of trees per ha at a canopy coverage of $80 \%$.

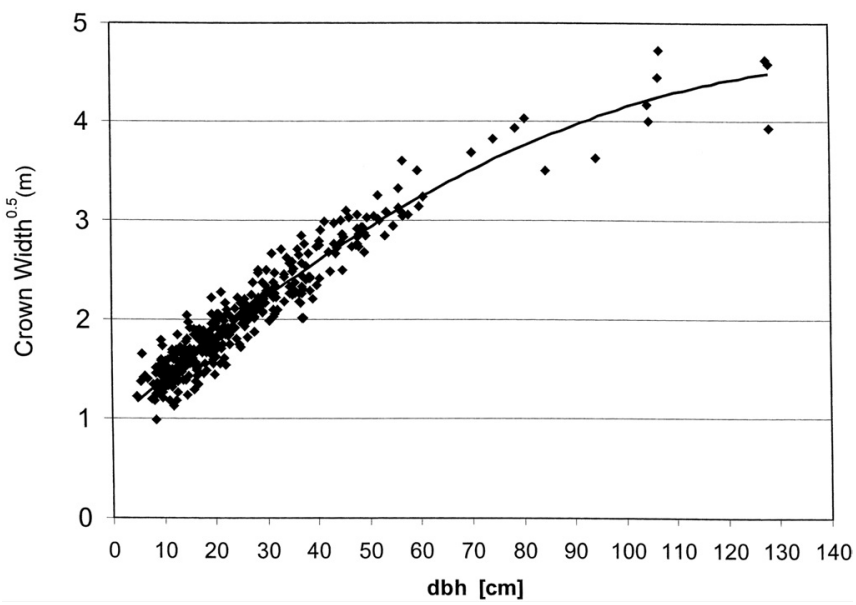

Figure 4. Crown width $(c w)$ of Parana pine and its relationship to $d b h$.

\subsection{Developing guidelines for managing stem diameter growth}

Our work so far has demonstrated that a close relationship exists between stem diameter and crown diameter. Indeed, stem diameter growth can be manipulated by thinning stands to reduce or enlarge growing space that is available to trees. We

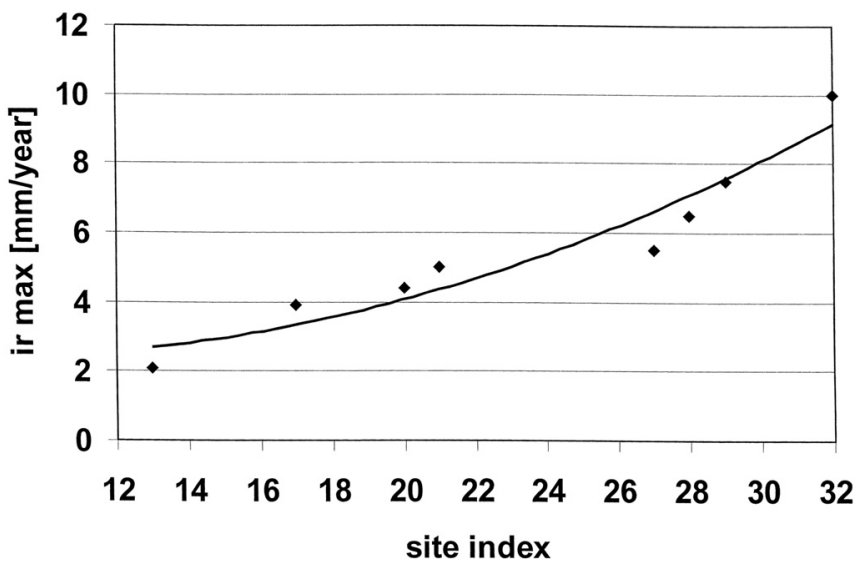

Figure 5. Regression between maximum radial increment (ir max) and site index.

assume that space created by thinning stands is quickly occupied by the remaining trees growing on good sites while on poorer sites the rate of occupation is slower. So site quality does not only influence height growth but also the horizontal growth of the crown. Table III shows the effect of varying ages, site indices, and maximum radial increment on stand density (numbers of trees) and potential $d b h$. 
Table IV. Estimated values of the parameters of the multiple linear regression of height of crown base on age, height and $d b h$ together with associated relevant statistics.

\begin{tabular}{lccccc}
\hline Variable & Estimated parameter & Standard error & $\begin{array}{c}\text { T to H0: } \\
\text { parameter }=0\end{array}$ & Prob $>|\mathrm{T}|$ & Variance inflation factor \\
\hline Intercept & -2.585 & 0.2497 & -10.352 & 0.0001 & 0.00000 \\
Age & 0.120 & 0.0082 & 14.675 & 0.0001 & 1.8092 \\
$h$ & 0.781 & 0.2906 & 26.893 & 0.0001 & 4.6336 \\
$d b h$ & -0.101 & 0.1302 & -7.745 & 0.0001 & 4.7752 \\
\hline
\end{tabular}

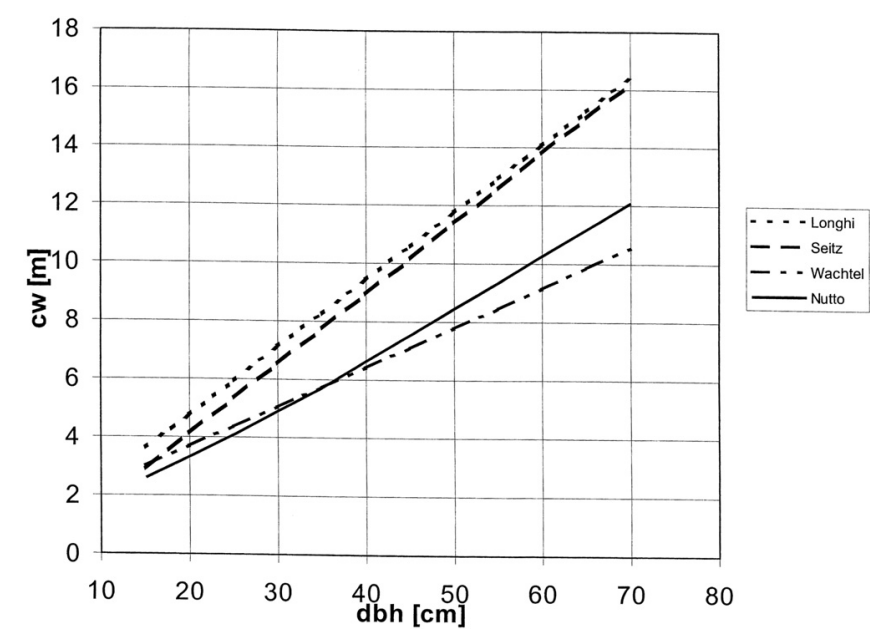

Figure 6. Comparison of three crown width models (Longhi 1980; Seitz 1986 and Wachtel 1990) with the model found in this study (Nutto).

We assume in Table III that the trees grow at a constant maximum radial increment over the whole rotation period until the target diameter is reached. The assumption of a constant radial increment facilitates the demonstration of the potential and applicability of the model. The crown width is the crown width needed to sustain a given radial growth. The number of trees per hectare is calculated by knowing the space needed for an individual tree with a given sized crown and also assuming a canopy coverage of $80 \%$. This canopy coverage was the mean value of all 16 plots we measured.

We have compared our crown width model with three existing crown width models; a model developed by Wachtel [36], one by Longhi [16], and one by Seitz [31] (Fig. 6).

Our model agrees closely with Wachtel's [36] model which differs from Longhi's [16] and Seitz's [31] in that our model predicts a smaller crown diameter for a given stem $d b h$. There are some possible explanations for why the models differ in predicting crown width. Longhi [16] calculated crown width by averaging two largest crown diameter measurements. According to studies by Huber and Röhle [11] this may overestimate the actual crown size while calculating crown diameter using eight rays (as was done in our study) results in a more accurate estimate of crown diameter. Seitz [31] used only 17 dominant trees that were heavily released. We would argue that the trees in Seitz's [31] study had a lower crown efficiency per unit crown area because of the way in which they were treated. Support for this argument comes from the work of Mayer [18] and also Sterba and Amateis [35] that show within a given crown class, small crowns are more efficient than large ones because their ratio between crown surface and horizontal crown projection is higher. Of course, in extreme situations, such as with trees grown to a certain diameter but in the process of dying (without live crown) and therefore with an infinite productivity, this consideration is not useful (see Spiecker [33]).

\subsection{Height to crown base}

Our working hypotheses is that natural pruning of branches is related to and can be estimated by tree height, $d b h$, and age. Height at a certain age is commonly used to indicate site quality, whereas diameter reached at that age corresponds to the rate of radial growth over time (age). This helps explain why we see relatively high correlations among these variables that we intend to use as predictor variables in a multiple linear regression (Tab. II).

The equation used to estimate the height to the base of the crown is

$$
c b=-2.585+0.12 \text { age }+0.781 h-0.101 d b h
$$

where $c b$ is height from ground to base of the live crown (m), $\mathrm{h}$ is total tree height $(\mathrm{m})$, age is age of tree in years, and $d b h$ is diameter $(\mathrm{cm})$ at $1.3 \mathrm{~m}$ above ground; $R^{2}$ (adjusted) $=0.90$, $S_{\mathrm{y} . \mathrm{x}}=1.501$, all variables very highly significant $(P<0.0001)$. The stepwise procedure identified age as accounting for the most variability in the height to the base of the crown (partial $R^{2}=0.83$ ) whereas height and $d b h$ contributed $4.7 \%$ and $1.6 \%$ respectively [28]. Initially we were concerned about the stability of the coefficients in the regression equation because of the relatively high correlations among age, height, and $d b h[1,6]$. Table IV details the statistics associated with the estimated parameters and shows that all are very highly significant $(P<0.0001)$ and that the issue of multicollinearity among the independent variables is of little concern because the variance inflation factor has a value less than $10[2,6]$.

Furthermore, analysis of the residual errors showed no unusual patterns that would suggest an inappropriate model or violation of assumptions underlying the regression procedure.

The model is also consistent in terms of the biology of the system. Both height and age have a positive sign which means as height and age increase so does the height of the crown above ground. On the other hand, $d b h$ has negative sign which means 
as $d b h$ increases, all other factors remaining constant, the base of the crown will be closer to the ground. This is consistent with our observations that trees that increase their diameter quickly will retain branches longer; therefore to improve quality we would have to prune. On the other hand, stands should be retained at high densities in order to reduce fast diameter growth and encourage natural pruning.

\subsection{Height of the lowest dead branch}

A simple linear regression was used to fit a line to an observed data set consisting of paired measurements of height to the base of the crown and height of the lowest dead branch from 388 trees. The resulting equation was

$$
l d b=-1.957+0.919 c b
$$

where $l d b$ is the height $(\mathrm{m})$ of the lowest dead branch above ground and $c b$ is the height $(\mathrm{m})$ above ground of the base of the crown; $r^{2}=0.83, S_{\mathrm{y} . \mathrm{x}}=1.74, P<0.0001$. In general, the lowest dead branch was found about $2 \mathrm{~m}$ below the base of the crown (Fig. 7).

\subsection{Applying the models to describe natural pruning}

Two major factors influence natural pruning of trees; diameter growth (growing space) and height growth. In general height growth depends on site quality and is very difficult to manipulate using silvicultural methods. On the other hand, diameter growth can easily be controlled by managing stand density (Tab. IV).

Figure 8 illustrates the difference in natural pruning between two trees growing on the same site but having different radial increments. Heights to the live crown base and to the first dead branch are higher for the tree with the slower diameter growth than for the tree with the higher diameter growth. Trees with fast diameter growth will have a correspondingly low height to crown base thereby resulting in a larger knotty core and reduced value.

If diameter growth (density) is held constant, we see that site index also influences natural pruning. Height of the crown base and height to the first dead branch occur higher on the stem of trees

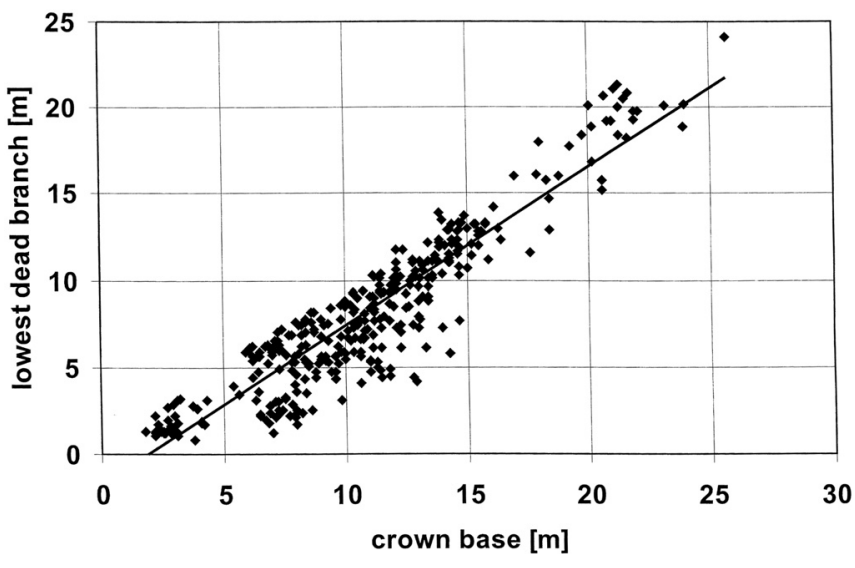

Figure 7. Commercial height or lowest dead branch related to the height of the crown base. Ten data values were classified as outliers and eliminated (not shown).

growing on sites having a high site index rather than a low one. This means that if natural pruning is to occur at the same height on the stem on trees growing on sites of differing quality, diameter growth has to be reduced on sites of lower site index (Fig. 9).

\subsection{Size of the knotty core}

The size of the knotty core of Parana pine stems can be determined using the models we have developed in this report. We demonstrate this by using as an example height growth derived from height curves from the yield table of Schneider and Oesten [29]. We express diameter growth as varying radial increments. Given these data we calculate the height of the first dead branch above ground. Knowing that Parana pine has an average rate of taper of $3 \%$ (Schneider, pers. communication) of diameter per meter, we then calculate the dimension of the knotty core (Fig. 10).

Figure 10 shows that timber without knots can be significantly increased by reducing diameter increment. But this also means a longer rotation period would be needed to achieve a

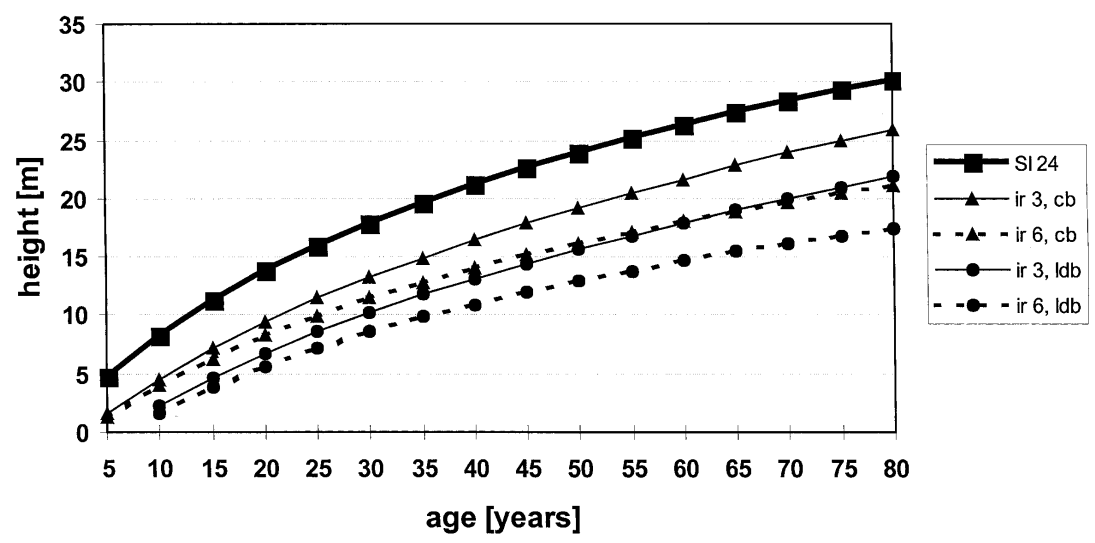

Figure 8. Comparison of the influence of diameter growth on natural pruning. Height shown is for site index 24 using yield tables of Schneider and Oesten (1999), height of crown base $(c b)$ and height to lowest dead branch (ldb) for two radial increments (ir) (3 and $6 \mathrm{~mm} / \mathrm{year})$. 


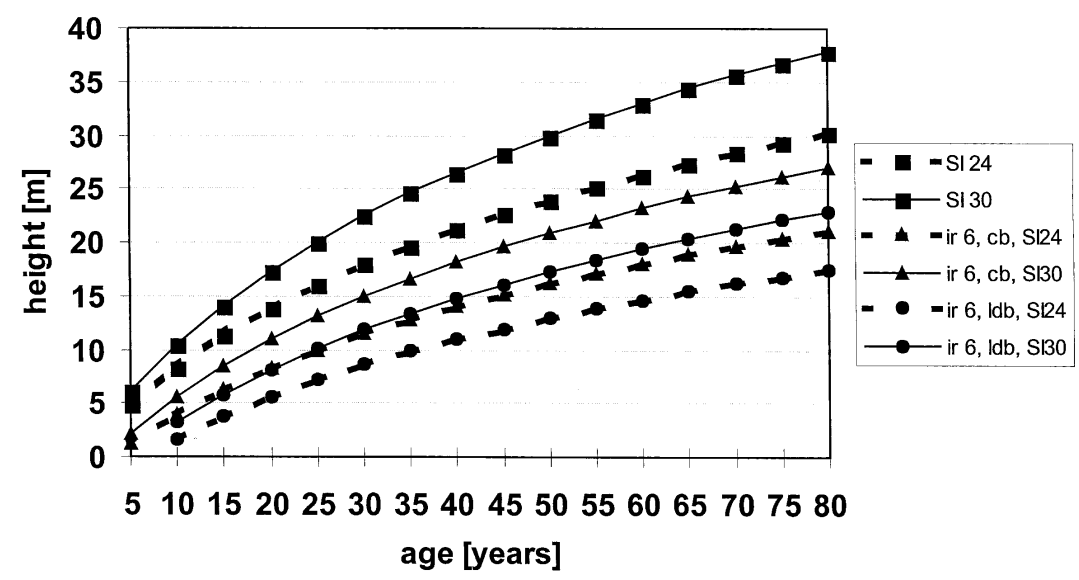

Figure 9. Influence of site index on the height of the crown base and height to lowest dead branch keeping radial increment (ir) constant (6 mm/ year) (Schneider and Oesten [29]).

specified diameter goal. In this example, the difference in rotation length is 27 years; the rotation length is 63 years for the tree growing in radius at $4 \mathrm{~mm} /$ year while the rotation length for the tree growing in radius at $7 \mathrm{~mm} /$ year is only 36 years. However, the slower growing tree has a volume of $3.28 \mathrm{~m}^{3} \mathrm{yr}^{-1}$ up to the height of the lowest dead branch which is $20 \mathrm{~m}$. The volume of the knotty core is $0.56 \mathrm{~m}^{3}$ which leaves $2.7 \mathrm{~m}^{3}$ of clear volume. On the other hand, the height to the lowest dead branch on the tree with the faster $d b h$ growth is much lower at $12 \mathrm{~m}$ and therefore has a reduced volume of only $1.97 \mathrm{~m}^{3}$. More importantly the volume of the knotty core is $0.75 \mathrm{~m}^{3}$ while the volume of clear wood is $1.22 \mathrm{~m}^{3}$ a reduction of $57 \%$ compared to the slower growing tree.

Thus, the volume of wood free of knots, especially within the first 6 to $10 \mathrm{~m}$, can be increased if diameter growth is reduced. This means keeping stands at high densities longer. The difficulty for the forest manager is to find a compromise between the dimension of the knotty core and costs of planting and artificial pruning, the rotation period, and the diameter goal at the end of the rotation period. Schultz [30] recommended that a sheath of clear wood without knots should be at least $2 / 3$ of the diameter of the timber used for sawn wood or veneer. He also states that $60 \%$ of the tree's value is contained within the first $4 \mathrm{~m}$ of the stem. However, clear wood is difficult to achieve naturally especially with the relatively low target diameters and short rotations of 30 to 40 years of Parana pine in southern Brazil. The only reasonable alternative is to artificially prune Parana pine in order to increase the proportion of valuable timber coming from this species.

Our models can be used to find out if natural pruning will satisfy management objectives for Parana pine. If not, then artificial pruning needs to be considered. The most reasonable procedure would be to remove all dead branches thus maintaining the height of the lowest dead branch at the base of the live crown. But this may not be sufficient to produce high quality wood. Live branches may also have to be removed.

Table V shows that in the first 10 to 15 years $40 \%$ of the desired diameter at rotation age has been reached but that the trees still retain a considerable part of their productive green crowns. For Parana pine no recommendations could be found but for loblolly pine (Pinus taeda L.) artificial pruning can be done to these trees as long as crown ratio remains above $40 \%$ [3]. Moreover changes in height growth dynamics are occurring rapidly at this age. According to Hawley and Smith [10],

Table V. The dynamics of natural pruning of Parana pine growing on a site with site index 30 and radial growth of $7 \mathrm{~mm} / \mathrm{year}$.

\begin{tabular}{lccccc}
\hline Age & $\begin{array}{c}\text { Height }(\mathrm{m}) \\
\text { (SI 30, Schneider and } \\
\text { Oesten [29]) }\end{array}$ & $\begin{array}{c}\text { Height of lowest } \\
\text { dead branch } \\
(\mathrm{m})\end{array}$ & $\begin{array}{c}\text { Height above ground } \\
\text { of crown base } \\
(\mathrm{m})\end{array}$ & $\begin{array}{c}\text { Crown ratio } \\
(\%)\end{array}$ & $\begin{array}{c}d b h(\mathrm{~cm}) \\
(\mathrm{ir}=7 \mathrm{~mm} / \mathrm{year})\end{array}$ \\
\hline 5 & 6.09 & & 2.1 & 66 & 7 \\
10 & 10.42 & 3.0 & 5.4 & 62 & 14 \\
15 & 14.12 & 5.5 & 8.2 & 53 & 21 \\
20 & 17.30 & 7.7 & 10.5 & 47 & 38 \\
25 & 20.60 & 9.6 & 12.6 & 44 & 42 \\
30 & 11.3 & 14.4 & 42 & 49 \\
35 & 22.47 & 12.7 & 16.0 & 40 & 56 \\
40 & 24.61 & 14.0 & 17.4 & 39 & 56 \\
\hline
\end{tabular}




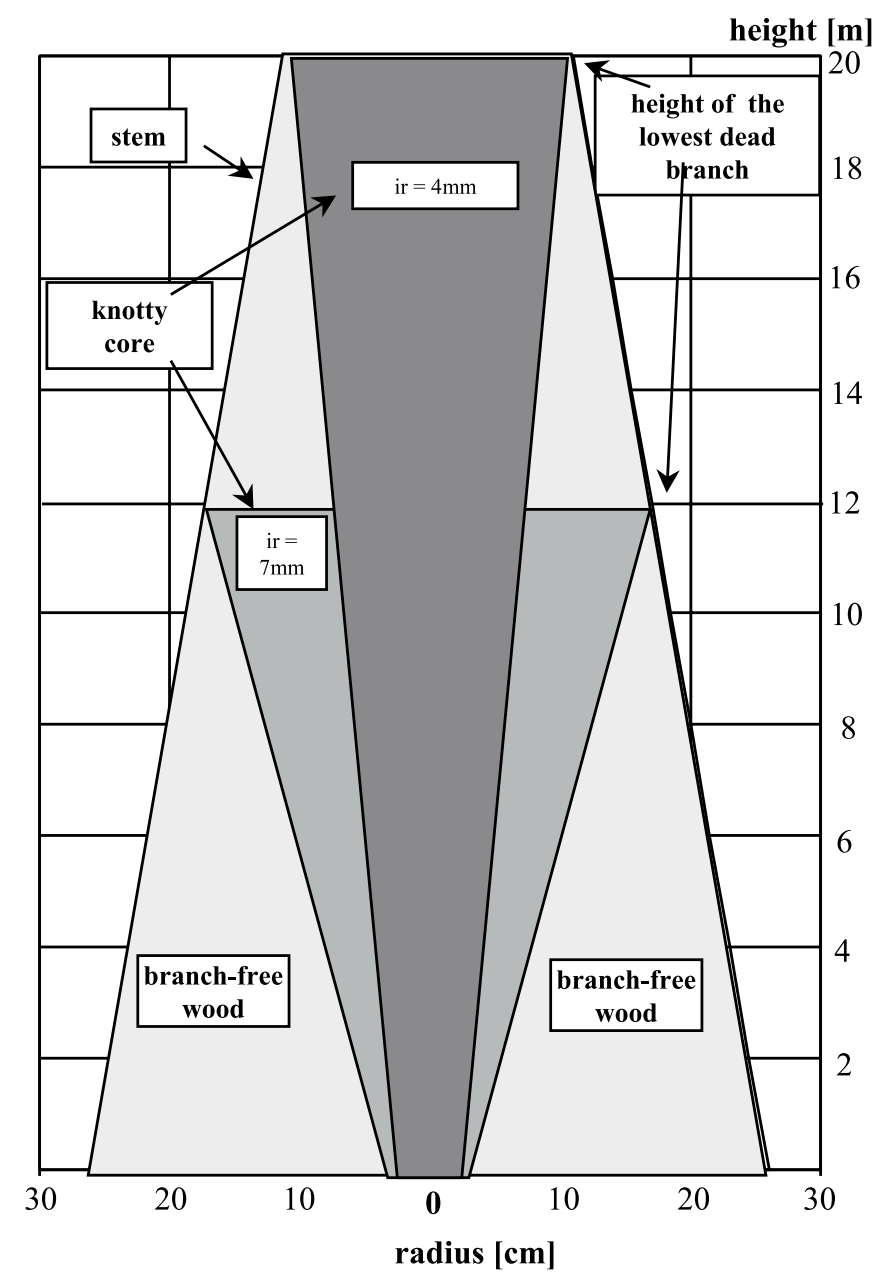

Figure 10. Knotty core of 2 growth variants. Height growth according to site index 28 (Schneider and Oesten 1999).

height growth is the best criterion to use when determining the tolerable intensity of pruning live crowns. Diameter and height growth generally are not affected by moderate levels of artificially pruning live crowns especially in the younger stages of tree growth [21]. In fact, Mitscherlich and von Gadow [20] state that branches of the lower part of the crown can even reduce increment because of respiration losses.

The data in Table $\mathrm{V}$ and Figure 11 show that pruning to a height of $3 \mathrm{~m}$ at age 5 and a second pruning up to $6 \mathrm{~m}$ at age 9 can significantly improve the quality of the stem without negatively influencing long term diameter growth.

\section{CONCLUSION}

A close relationship exists between crown diameter and stem diameter at breast height that can be used to estimate the amount of growing space a tree needs in order to maintain a certain stem diameter $(d b h)$ increment. Fortunately, growing space can be manipulated by regulating the crown sizes of trees through varying stand density by thinning around individual trees. Decisions made based on these relationships can produce high qual-

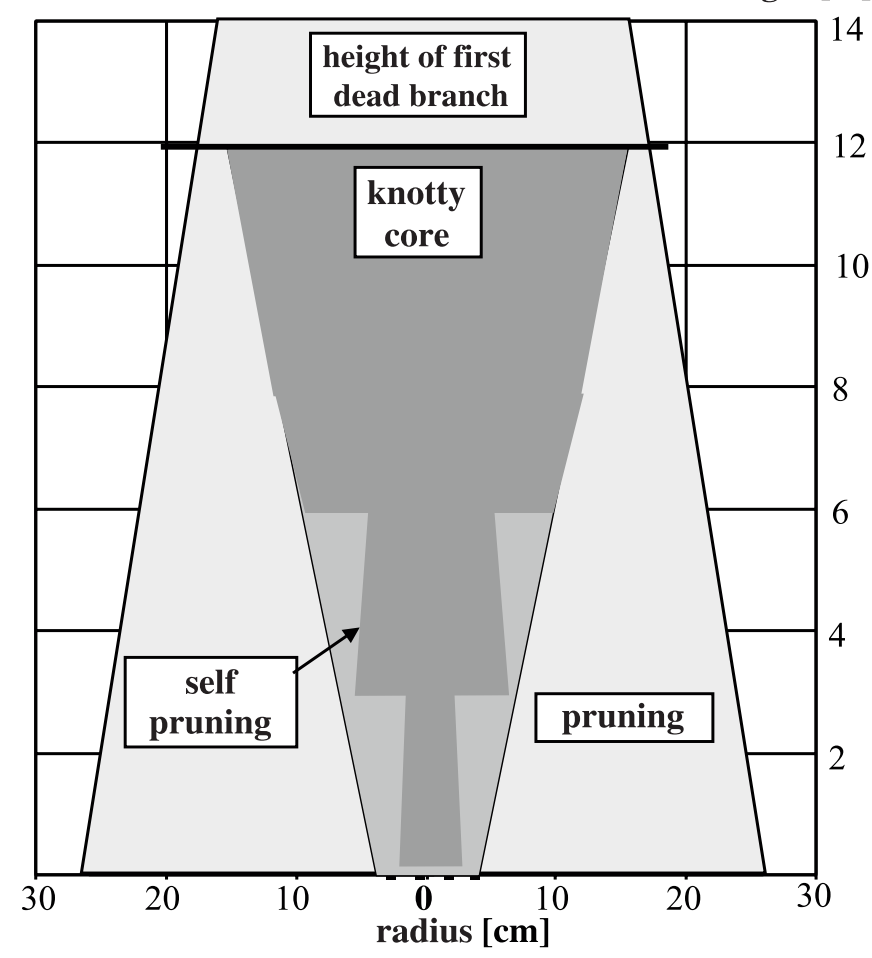

Figure 11. Comparison of the knotty core formed with under natural pruning or with artificial pruning (at the age of 5 and 10 years at $40 \%$ of crown ratio) for Parana pine growing on site index of 30 (Schneider and Oesten 1999) with a radial increment of $7 \mathrm{~mm} / \mathrm{year}$.

ity timber by focusing silvicultural treatments on only a few selected "crop" trees. However, in order for these treatments to be successful maximum radial increment needs to be determined by site quality.

Natural pruning in trees is mainly related to growing space, age and site index. Since height growth is highly related to site quality which is difficult to manipulate silviculturally, we sought to manage natural pruning by focusing on the relation between pruning and diameter growth. Therefore we used the variables of $d b h$, height, and age and their relation to growing space to allow us to predict maximum radial growth, height to base of crown, and height to the first dead branch.

Whereas a higher height growth accelerates natural pruning, increasing diameter growth slows down this process. Consequently the best natural pruning occurs on sites with high quality (site index) given the same $d b h$ growth. On the other hand it is possible to improve natural pruning by keeping stands at a high initial density. In this case diameter growth is slower, thereby causing longer rotation periods to reach target $d b h$ 's.

Timber quality as it relates to the knotty core of Parana pine can be calculated using the models we have developed in this article. Thus the efficacy of natural pruning can be evaluated. For situations where natural pruning is insufficient to produce high quality timber within a desired time frame, an artificial pruning program can be developed, especially for shorter rotation periods and target diameters of 40 to $50 \mathrm{~cm}$. Once pruning 
activities are finished the volume of the knotty core remains constant and the wood outside this core increases in value as the diameter of the tree increases. This might be a sufficient incentive to lengthen rotation ages and produce trees of greater diameters.

Even though this study includes a wide range of age, $d b h$, site qualities and treatments in natural and planted forests of Parana pine, further studies using more material to conduct detailed pruning experiments would be useful to compare and contrast the results of our work.

Acknowledgments: We thank Saulo José Barbieri, Forest Engineer and Chief of the Forest Planning Sector and Vilmar de Souza Brasil, Technician, of the company ARAUPEL S.A, Quedas do Iguaçu, Paraná, Brazil. We acknowledge the help of Forest Engineer Flavio Mendes of the company CELUCAT S.A, Correia Pinto, Santa Catarina, Brazil. The present work was made possible with support of the Postdoctoral program HSP III of the Government of the Federal Republic of Germany, under coordination of the DAAD.

\section{REFERENCES}

[1] Backhaus K., Multivariate Analysemethoden: eine anwendungsorientierte Einführung, 6. Auflage, Springer, Berlin, 1990, 416 p.

[2] Belsley D.A., Kuh E., Welsch R.E., Regression Diagnostics: Identifying influential data sources of collinearity, Wiley \& Sons, New York, 1980, 292 p.

[3] Bonamigo A., Manejo Florestal na Cambará S.A. Produtos Florestais, In: Proceedings of the $1^{\circ}$ Simpósio Latino-Americano sobre Manejo Florestal, 2000, pp. 143-148.

[4] Dawkins H.C., Crown diameters: their relation to bole diameter in tropical forest trees, Commonw. For. Rev. 42 (1963) 318-333.

[5] Deleuze C., Herve J.-C., Colin F., Ribeyrolles L., Modelling crown shape of Picea abies: spacing effects, Can. J. For. Res. 26 (1996) 1957-1966.

[6] Draper N.R., Smith H., Applied Regression Analysis, 3rd ed., Wiley \& Sons, New York, 1998, 706 p.

[7] Duchaufour A., L'aménagement de la forêt de Compiègne, Rev. Eaux For. 42 (1903) 65-78.

[8] Golfari L., Coniferas aptas para repoblaciones forestales en el Estado de São Paulo, Silvicultura em São Paulo 6 (1967) 7-62.

[9] Hartung J., Elpelt B., Multivariate Statistik, Oldenbourg Verlag, München, 1984, $806 \mathrm{p}$.

[10] Hawley R.C., Smith D.M., Silvicultura prática, Omega, Barcelona, $1972,544 \mathrm{p}$.

[11] Huber W., Röhle H., Untersuchungen zur Methode der Ablotung von Kronenradien und der Berechnung von Kronengrundflächen, Forstarchiv 56 (1985) 238-243.

[12] Hueck K., As florestas da América do Sul, Polígono, São Paulo, 1972, $466 \mathrm{p}$.

[13] IBAMA, Portaria No. 71, Sistema de controle de madeira contingenciada para as especies florestais Swietenia macrophylla, Virola surinamensis, Araucaria angustifolia e Ocotea porosa, 1994.

[14] Kozlowski T.T., Growth and development of trees, Academic Press, New York, 1971, 514 p.

[15] Lamprecht H., Waldbau in den Tropen: die tropischen Waldökosysteme und ihre Baumarten - Möglichkeiten und Methoden zu ihrer nachhaltigen Nutzung, Paul Parey, Hamburg, 1986, 318 p.

[16] Longhi S.J., A estrutura de uma floresta natural de Araucaria angustifolia (Bert.) O. Ktze., no Sul do Brasil, Master's thesis, Federal University of Parana, 1980, 198 p.
[17] Machado S.A., Siqueira J.D.P., Distribuição natural de Araucaria angustifolia (Bert.) O. Ktze, in: Anais da conferência IUFRO Problemas florestais do gênero Araucaria, Curitiba, 1980, pp. 4-9.

[18] Mayer R., Kronengröße und Zuwachsleistung der Traubeneiche auf süddeutschen Standorten, Allg. Forst- u. J.-Ztg. 129 (1958) 105114, 151-163, 191-201.

[19] Mayer-Wegelin Ästung H., Hannover, M.\&H. Schaper, 1936, $178 \mathrm{p}$.

[20] Mitscherlich G., Gadow K.V., Über den Zuwachsverlust bei der Ästung von Nadelbäumen, Allg. Forst- u. J.-Ztg. 139 (1968) 175185.

[21] Montagna R.G., Fernandes P.S., Rocha F.T., Florsheim S.M.B., Couto H.T.Z. do, Influência da desrama artificial sobre o crescimento e a densidade básica da madeira de Pinus elliottii var. elliottii, in: Serie Tecnica Ipef, Piracicaba 9, 1993, pp. 35-45.

[22] Moreno J.A., Clima do Rio Grande do Sul, Porto Alegre: Secretaria da Agricultura-RS, 1961, $41 \mathrm{p}$

[23] Nelson N.D., Burk T., Isebrands J.G., Crown architecture of shortrotation intensively cultivated Populus. I. Effects of clone and spacing on first-order branch characteristics, Can. J. For. Res. 11 (1981) 73-81.

[24] Nutto L., Neue Perspektiven in der Begründung und Pflege von jungen Eichenbeständen: Ergebnisse einer Untersuchung zur Kronenentwicklung, Astreinigung und Dickenwachstum junger Stielund Traubeneichen in Europa (Quercus robur L. und Quercus petraea (Matt.) Liebl.), Schriftenreihe Freiburger Forstliche Forschung, Band 5, Freiburg i. Brsg., 1999, 190 p.

[25] Nutto L., Spiecker H., Production of valuable wood: a software aided decision tool for managing oak stands in Europe, in: Improvement Of Wood Quality And Genetic Diversity Of Oaks, Annales Experimentalis Silvarum Culturae Provehendis, No. 34, Zagreb, Croatia, 2000, pp. 37-49.

[26] Pretzsch H., Perspektiven einer modellorientierten Waldwachstumsforschung, Forstwiss. Centralbl. 114 (1995) 188-209.

[27] Röhle H., Vergleichende Untersuchungen zur Ermittlung der Genauigkeit bei der Ablotung von Kronenradien, Forstarchiv 57 (1986) 67-71.

[28] SAS Insitute, SAS User Guide, Cary, North Carolina, 1989, 1029 p.

[29] Schneider P.R., Oesten G., Tabelas auxiliares para o manejo de Araucaria angustifolia e Pinus elliottii para a região do planalto médio do Rio Grande do Sul, CEPEF, Universidade Federal de Santa Maria, 1999, 118 p.

[30] Schulz H., Untersuchungen über die Bewertung und Gütemerkmale des Eichenholzes aus verschiedenen Wuchsgebieten, Schriftenreihe der Universität Göttingen, No. 23, 1959, 90 p.

[31] Seitz R., Erste Hinweise für die waldbauliche Behandlung von Araukarienwäldern, Ann. Sci. For. 43 (1986) 327-338.

[32] Shigo A.L., Tree decay: An expanded concept, USDA For. Serv. Agric. Inf. Bull. No. 419, 1979, 73 p.

[33] Spiecker H., Zur Steuerung des Dickenwachstums und der Astreinigung von Trauben- und Stieleichen, Schriftenreihe der Landesforstverwaltung, Bad.-Württ. 72, 1991, 155 p.

[34] Sterba H., Concepts and techniques for forest growth models, in Conferência IUFRO Artificial Intelligence And Growth Models For Management Decisions, Vienna, Proceedings, 1989, pp. 13-20.

[35] Sterba H., Amateis L., Crown efficiency in a loblolly pine (Pinus taeda) spacing experiment, Can. J. For. Res. 28 (1998) 1344-1351.

[36] Wachtel G., Untersuchungen zu Struktur und Dynamik eines Araukarien-Naturwaldes in Südbrasilien, Dissertation Universität Freiburg, 1990, $180 \mathrm{p}$.

[37] Whitmore T.C., Tropical Rain Forests of the Far East, Clarendon Press, Oxford, England, 1975, 282 p. 